J. Asiat. Soc. Bangladesh, Sci. 44(2): 211-224, December 2018

\title{
ASSESSMENT OF FLOOD RISK IN THE EASTERN PART OF JAMUNA FLOODPLAIN
}

\author{
MARUF BILLAH ${ }^{1} *$ AND MEHEDI AHMED ANSARY ${ }^{2}$ \\ ${ }^{1}$ Institute of Water and Flood Management, Bangladesh University of Engineering \\ and Technology, Dhaka-1000, Bangladesh \\ ${ }^{2}$ Department of Civil Engineering, Bangladesh University of Engineering and \\ Technology, Dhaka-1000, Bangladesh
}

\begin{abstract}
Risk assessment provides the scope to understand the vulnerability situation of any area based on different hazard context. The study has been conducted in the eastern part of Jamuna floodplain area to examine its flood vulnerability. To perform the analysis, the whole study area has been surveyed and examined applying Geographic Information System. The entire hazard, vulnerability as well as the capacity factors are assessed and have been classified into different categories from very low to very high. Individual factor analysis has been considered to realize the specific condition of different factors. Finally, flood hazard map has been prepared to examine the vulnerability of the proposed area. This type of work helps the planners and disaster managers to identify the most risk zone which should receive immediate hazard mitigation measures as well as help to take a decision in an emergency situation when a flood may occur in the study area.
\end{abstract}

Key words: Flood hazard, Vulnerability, Capacity, Geographic information system

\section{Introduction}

Risk assessment is becoming popular in the management and policies of all the major countries especially in disaster management sector like a flood (Meyer et al. 2009). In the context of Bangladesh, risk assessment is even more important as she faces different natural calamities on a regular basis and flood is one of them. It noticeably damage humanlives, properties, environments and contributed about $39.26 \%$ of worldwide natural disasters and caused about US\$ 397.3 billion worth damage between 2000 and 2014 (Emdat 2010). As Bangladesh is part of the world's most dynamic hydrological and the biggest active delta system, the landscape, position, and outfall of the three major rivers shape the annual hydrological cycle of the land. Too much rain in rainy season and too little water in the dry season is the annual phenomenon in a hydrological cycle. Here regular monsoon event, flood, the depth, and duration of inundation are the deciding factors whether it is affecting beneficially or adversely. Monsoon inflow along with rainfall historically shapes the civilization, development, environment, ecology and the

*Author for correspondence: E-mail: marufbillah413@gmail.com 
economy of the country. Extreme events of flood adversely affect the development, economy, poverty and almost every sector. The quick advancement of satellite-based innovations and the remarkable advancements in spatial data examination and demonstration have empowered various improvements in exact flood risk evaluation and also rational flood management.

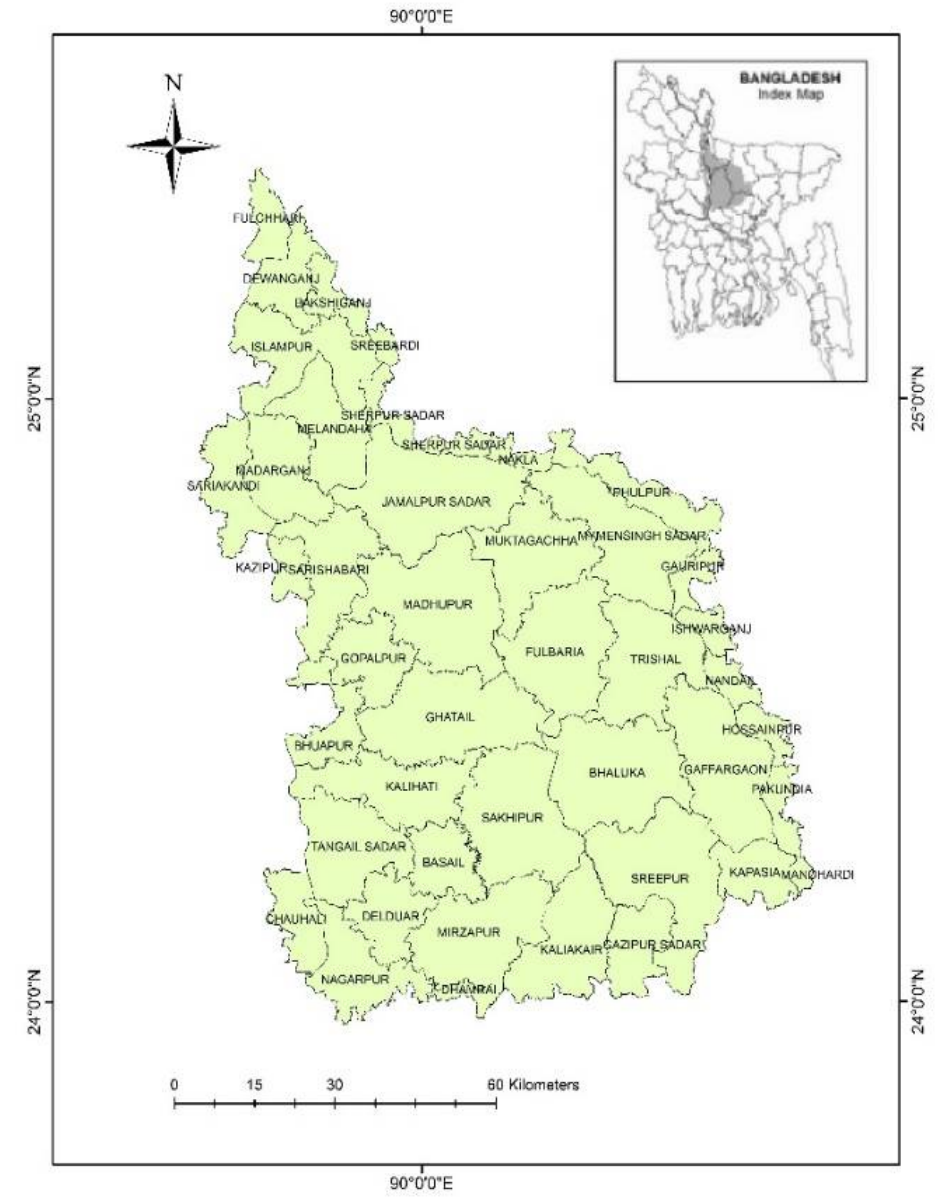

Fig. 1. Study area (Karzakram 2011).

\section{Materials and Methods}

The concept of risk: A risk is observed as the likelihood of occurrence or the gradation of loss of a specified element expected from a specific hazard (Schneiderbauer and Ehrlich 2004). While risk measurement varies according to discipline. In hazard research, a risk is equal to the product of two or three factors (Crichton 2002, Wisner et al. 2004), though 
dissimilar views exist (Chakraborty et al. 2005) . For example, (Crichton 2002) summaries chance with a three-way relationship in which risk, presentation, and helplessness contribute freely. On the other hand, Asian Disaster Reduction Center (Shaluf 2007) defines hazard as the coverage areas of three factors - hazard, exposure, and vulnerability - that act simultaneously to generate the risk of natural hazards, which can be expressed as:

$$
\begin{aligned}
& \text { Risk }=\text { Hazard } \times \text { vulnerability } \\
& \text { Risk }=\text { Hazard } \times \text { exposure } \times \text { vulnerability }
\end{aligned}
$$

While hazards are a probable threat to inhabitants and the surroundings, a risk is an interplay between hazard and vulnerability. Elements at risk, a commonly used term in hazard research, allows the assessment of economic losses from a life-threatening event (Meyer et al. 2009). But it is usually not included in the risk equation; it is considered as a part of the vulnerability and exposure analysis.

However, according to the United Nations Disaster Relief Coordinator Office (Peduzzi et al. 2009), a risk is the function of elements at risk (e.g., population), hazards, and vulnerability. It varies from the concept of others, who describe risk as a production of hazard and vulnerability (Wisner et al. 2004). The risk to a specific community varies over time and time and depends on their socio-economic, traditional, and other characteristics (Cannon 2000, Wisner et al. 2004). Moreover the risk of the natural hazards relay on both the hazard and the capability of the community to withstand shocks from disaster.

Risk assessment: Risk assessment refers to the evaluation of the capacity of estimated risks based on the local society's suitability criteria. Processed data and information have been used in the developed model and finally a risk map has been prepared using the following speculation:

$$
\text { Risk }=\frac{\text { Hazard } \times \text { vulnerability }}{\text { Coping capacity }} \quad \text { (Eq. 3) }
$$

Concept of flood risk assessment: Flood risk assessment is an interdisciplinary task. It combines various types of source, information and models. Some assessment attempts to estimate many possible hazard factors like flood extent and inundation depth, how probable they are and what may be the consequence (de Moel et al. 2015).

Integrated risk assessment model: Risk is the product of hazard, exposure, vulnerability, and coping capacity. Using these measures, hazard (the probability or severity of flood, elevation from sea level), exposure characterizes (structure, population, population 
density, distance from river), and capacity (awareness, relief system, economic strength, use of indigenous knowledge, education system), it is possible to determine community's risk to hazards and can take the necessary actions to lessen the risk of disaster. The proposed model was mainly developed to assess the flood risk of the Jamuna Floodplain. Hence, all these above-mentioned components are applicable to single hazard investigation. The model is based on three important principles.

First, a single hazard perspective is used rather than a multi-hazard.

Second, it is only applicable for hazards that have spatial relevance, such as the flood. Spatially non-relevant hazards such as disaster earthquake or cyclone cannot be used.

Third, the model may be useful to determine community risk by integrating hazard and vulnerability. However, it is unable to recognize individuals' risk. An important pitfall of this model is that it requires plentiful data to operationalize the concept.

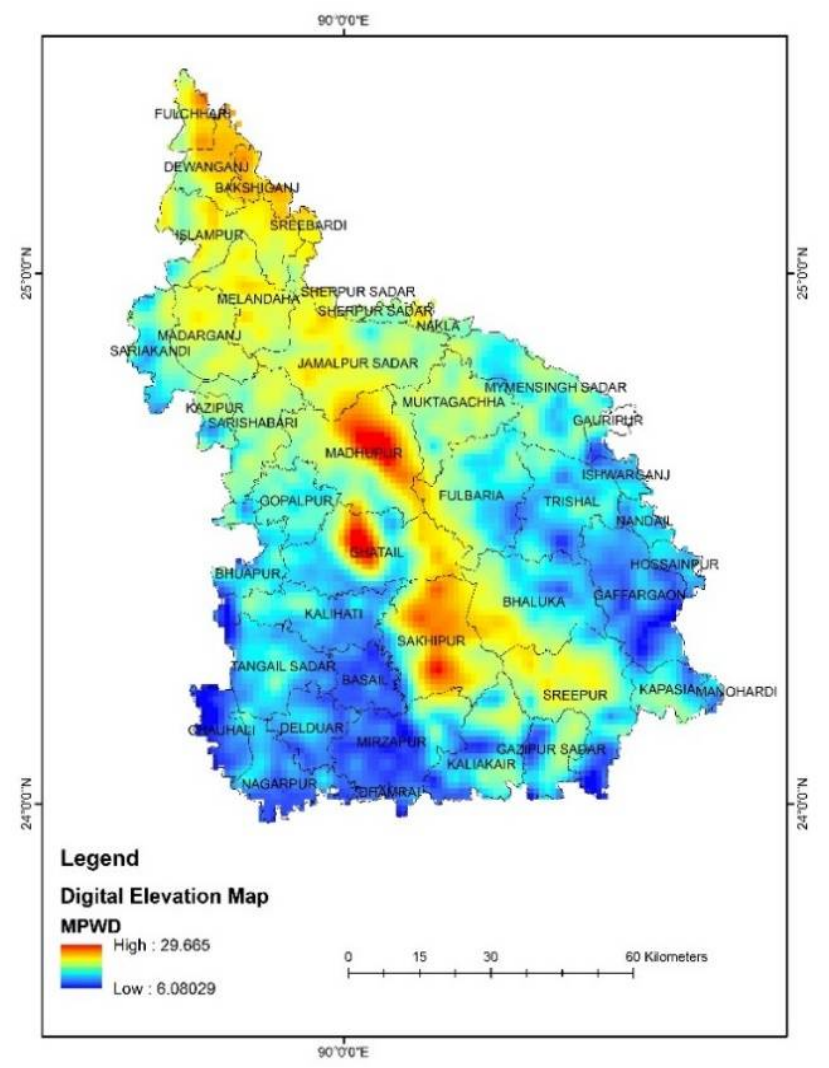

Fig. 2. Elevation map. 
Topographic analysis: For the purpose of using geographical data in the planned model, Upazilla map are constructed from an administrative shapefile provided by the Government of Bangladesh. GPX converter (an online open source) has been used to obtain elevation data for a particular area which was later processed and assembled into a spatial database using GIS and image processing (Fig. 2). According to the elevation of the study area elevation rank has been prepared on a map (Fig. 3).

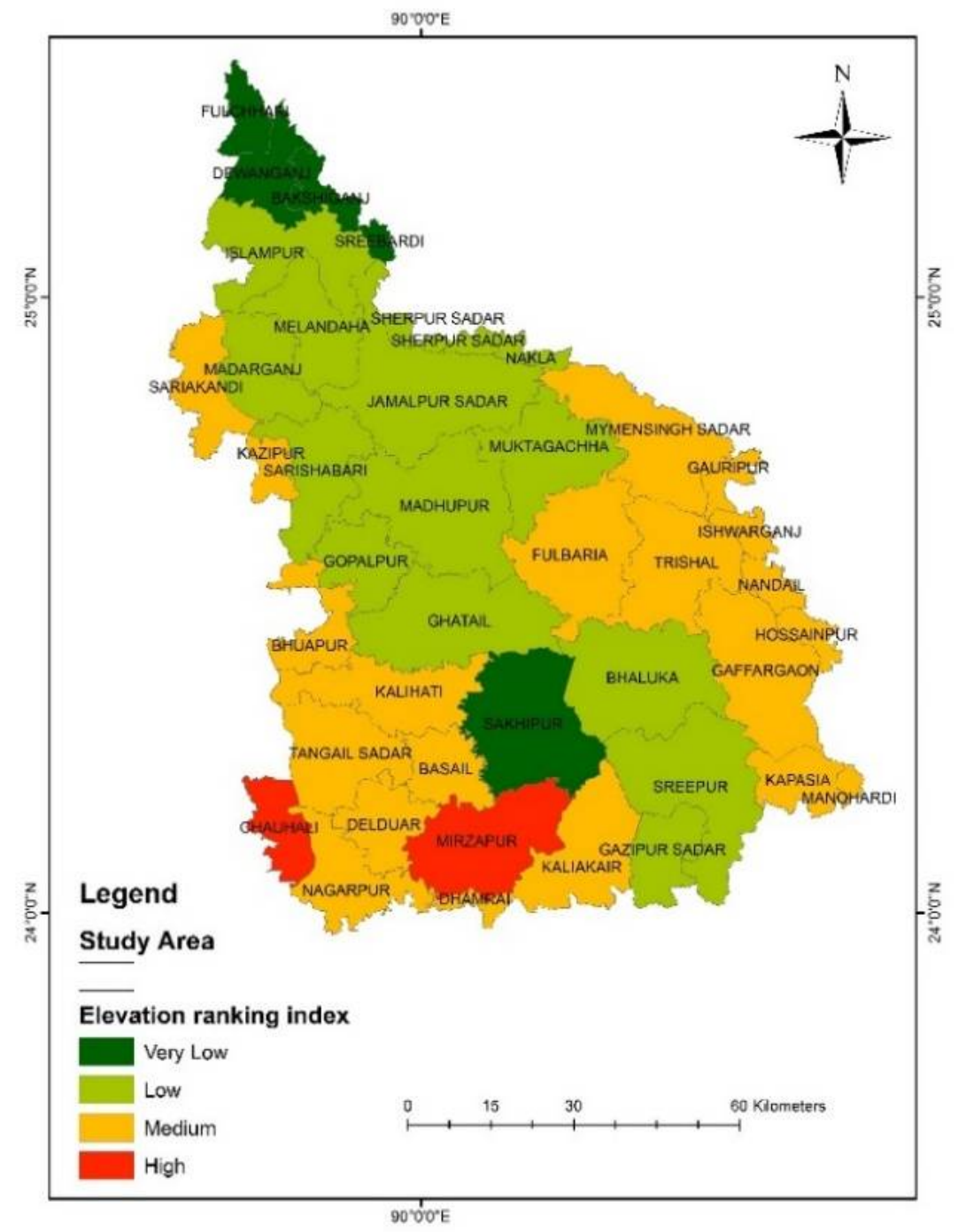

Fig. 3. Elevation ranking. 


\section{Analysis of variables of the proposed model}

Raster elevation ranked as 20 meters and above height from the sea level is 5 in rank, and 1 is in risk rank while very low in risk index. The estimated values, ranks and risk index are given in the Table 1.

Table 1. Elevation value, rank and index used in the model.

\begin{tabular}{lccl}
\hline & Values & Rank & Risk index \\
\hline $1-5$ & 1 & 5 & Very high \\
$6-10$ & 2 & 4 & High \\
$11-15$ & 3 & 3 & Medium \\
$16-20$ & 4 & 2 & Low \\
$20+$ & 5 & 1 & Very low \\
\hline
\end{tabular}

Source: Tingsanchali and Karim 2010.

Table 2. Upazilawise population density in the study area.

\begin{tabular}{llllll}
\hline SL. no. & $\begin{array}{l}\text { Name of the } \\
\text { Upazila }\end{array}$ & $\begin{array}{l}\text { Area }(\mathrm{sq} . \\
\mathrm{km})\end{array}$ & $\begin{array}{l}\text { Total } \\
\text { population }\end{array}$ & $\begin{array}{l}\text { Density/ sq. } \\
\mathrm{km}\end{array}$ & $\begin{array}{l}\text { Density } \\
\text { rank }(*)\end{array}$ \\
\hline 1 & Basail & 157.78 & 148555 & 941 & 2 \\
2 & Bhaluka & 444.05 & 264991 & 596 & 2 \\
3 & Delduar & 184.54 & 175684 & 952 & 2 \\
4 & Fulbari & 402.41 & 345283 & 858 & 2 \\
5 & Gafargaon & 401.16 & 379803 & 946 & 2 \\
6 & Ghatail & 451.30 & 341376 & 756 & 2 \\
7 & Gopalpur & 193.37 & 252747 & 1307 & 3 \\
8 & Jamalpur Sadar & 489.56 & 501924 & 1025 & 3 \\
9 & Kaliakair & 414.14 & 232915 & 741 & 2 \\
10 & Kalihati & 301.22 & 354959 & 1178 & 3 \\
11 & Madargonj & 225.38 & 24306 & 107 & 1 \\
12 & Madhupur & 500.67 & 375295 & 749 & 2 \\
13 & Melandaha & 239.65 & 262478 & 1095 & 3 \\
14 & Mirzapur & 373.89 & 337496 & 902 & 2 \\
15 & Muktagacha & 314.71 & 321759 & 1022 & 3 \\
16 & Sakhipur & 429.63 & 220281 & 512 & 2 \\
17 & Sharishabari & 263.48 & 289106 & 1097 & 3 \\
18 & Tangail Sadar & 334.26 & 680518 & 2035 & 5 \\
19 & Trisal & 338.98 & 336797 & 993 & 2 \\
\hline$*$ Population & density index, $100-500=1,501-1000=2,1001-1500=3,1501-2000=4$, \\
$2000+=5$ & & & & \\
\hline
\end{tabular}

Source: Bangladesh Bureau of Statistics 2011. 
Analysis of population density of human settlement: The population density of the study area provided further evidence of the problems especially in the case of losses of life due to flooding. To assess the flood risk on population settlement, Upazila wise population density statistics has been usedand shown in Table 2. A population density index map has been developed for better visualization (Fig. 4).

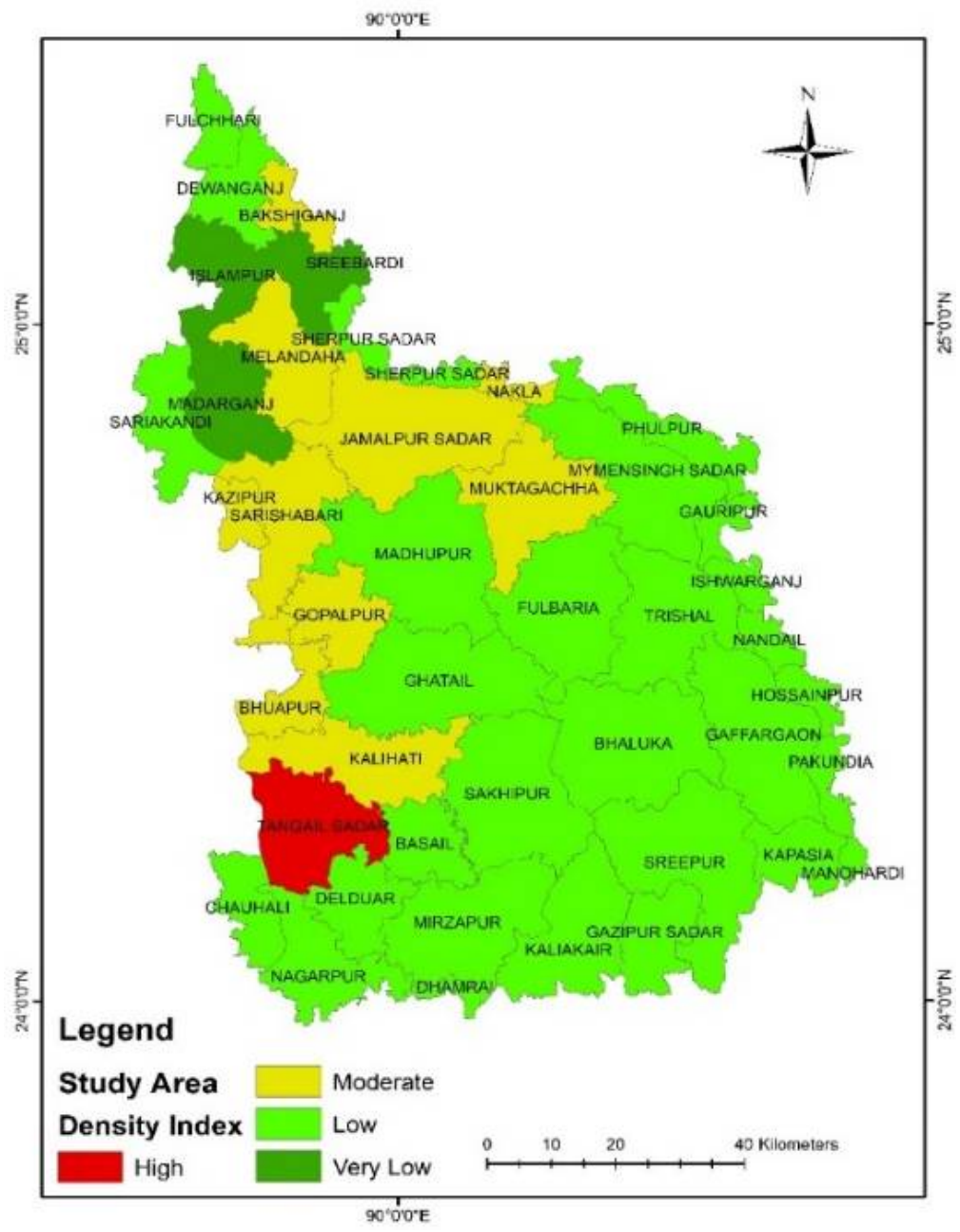

Fig. 4. Population density index.

Hydrological analysis: The vulnerability of flood in any catchment or basin area or floodplain depends on the hydrological characteristics of its own. To determine the actual scenario of hydrological risk, distance from the river of each unit of land (Upazila) 
calculated and in this case the river Jamuna has been taken into consideration as a river. Upazila wise distance rank has been prepared on the basis of a distance from the river. The distance has been calculated using proximity toolset in Arcgis 10.1 version. Fig. 5 represents the distant ranking.

Table 3. Hydrological data used in the model.

\begin{tabular}{llccc}
\hline Sl. No. & $\begin{array}{l}\text { Name of the } \\
\text { Upazila }\end{array}$ & $\begin{array}{c}\text { Area } \\
(\text { Sq. km })\end{array}$ & $\begin{array}{c}\text { Average distance } \\
\text { from the river }(\mathrm{Km})\end{array}$ & $\begin{array}{c}\text { Distance } \\
\text { rank } *\end{array}$ \\
\hline 1 & Basail & 157.78 & 38.62 & 3 \\
2 & Bhaluka & 444.05 & 51.49 & 4 \\
3 & Delduar & 184.54 & 24.14 & 1 \\
4 & Fulbari & 402.41 & 54.71 & 4 \\
5 & Gafargaon & 401.16 & 86.90 & 5 \\
6 & Ghatail & 451.30 & 32.18 & 1 \\
7 & Gopalpur & 193.37 & 8.04 & 1 \\
8 & Jamalpur Sadar & 489.56 & 40.23 & 3 \\
9 & Kaliakair & 414.14 & 65.98 & 5 \\
10 & Kalihati & 301.22 & 6.43 & 1 \\
11 & Madargonj & 225.38 & 9.65 & 2 \\
12 & Madhupur & 500.67 & 37.01 & 2 \\
13 & Melandaha & 239.65 & 25.74 & 3 \\
14 & Mirzapur & 373.89 & 41.84 & 4 \\
15 & Muktagacha & 314.71 & 59.54 & 3 \\
16 & Sakhipur & 429.63 & 45.06 & 1 \\
17 & Sharishabari & 263.48 & 14.48 & 5 \\
18 & Tangail Sadar & 334.26 & 17.70 & \\
19 & Trisal & 338.98 & 67.59 & 1 \\
\hline Distance & index, 0 - 16 $=1,17-32 ~$ & $2,33-48=3,49-64=4,65+=5$ & \\
\hline
\end{tabular}

Average vulnerability index: To calculate the average vulnerability of the selected area, population density and the distance from the river has been considered because the flood will affect more if it sticks in a densely populated area rather than an area which has less density. On the other hand distance from the river is another parameter as in our country maximum flood occurs when the river cannot contain the excessive water flow coming down from the upward in monsoon period. A vulnerability index map (Fig. 6) has been developed using the average score of the distance from the river and population density. 
Coping capacities or coping strategies: Coping capacities or coping strategies are highly complementary since greater resilience is achieved. People of the study area adapted various strategies to cope with the flood of their own and also with the help of different organizations. Focus group discussion (FGD), key informant interview (KII) have been conducted in every Upazilla. Coping strategies of the local people used in the developed model as furnished in the table below: (Table 4) and the map (Fig. 7) symbolize the overall capacity scenario of that specific area.

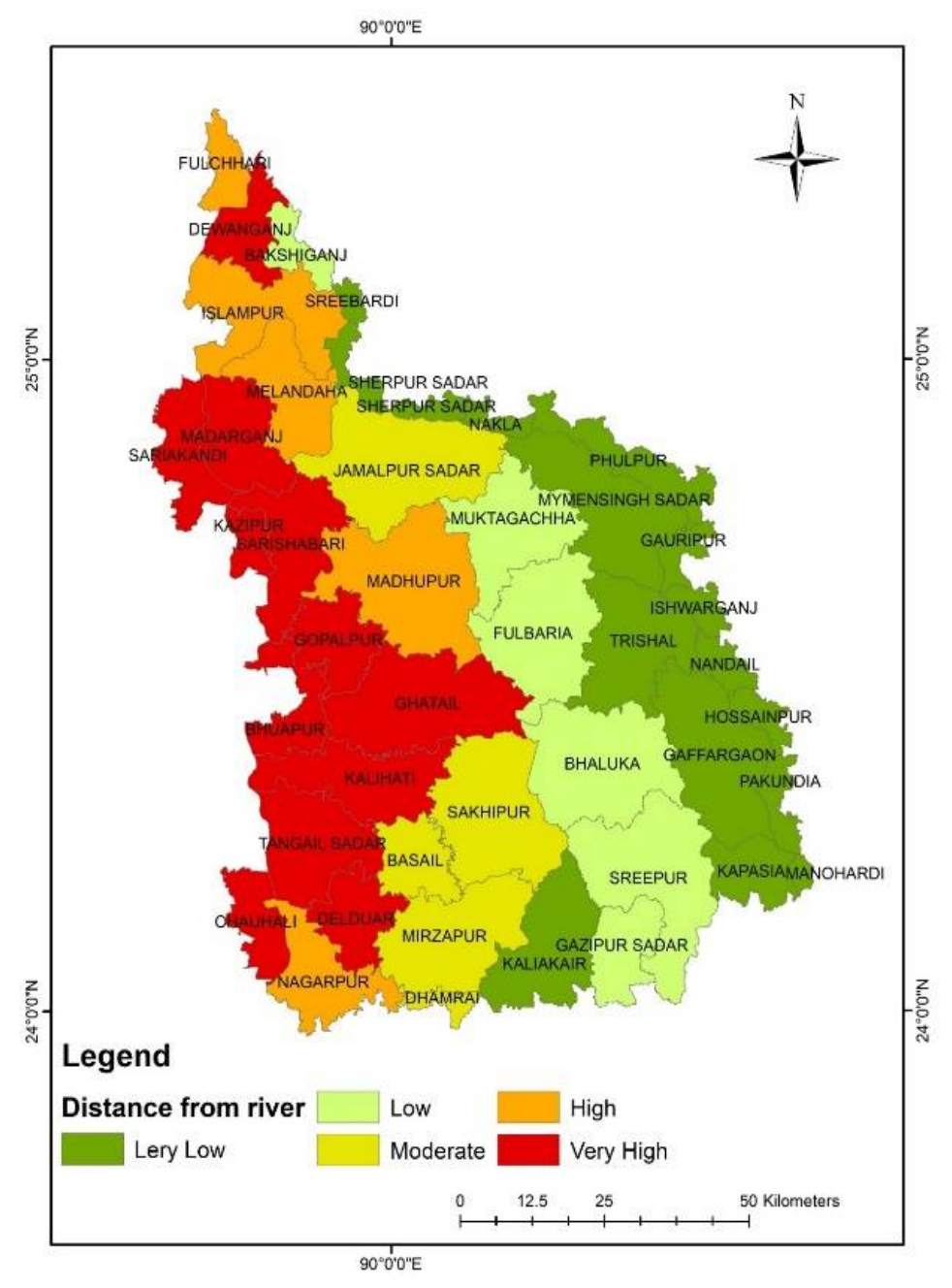

Fig. 5. Distant rank from the river. 


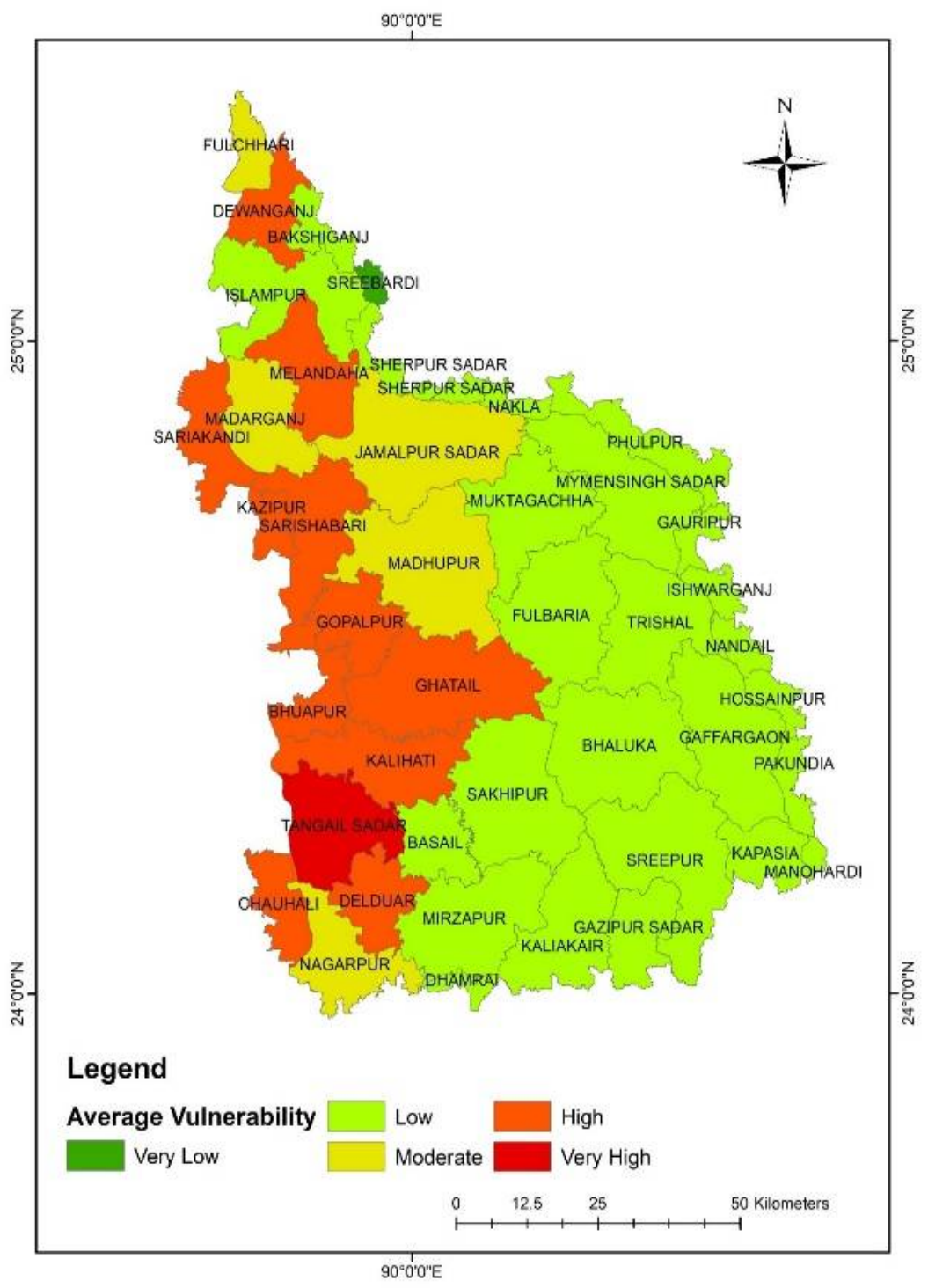

Fig. 6. Average vulnerability index.

Flood risk ranking map: Based on the assessment final risk has been calculated through the equation (Eq. 3). The developed model has run using Arc GIS and final flood risk map have been developed. In the case of the final output of the flood risk map, three major variables like hazard, vulnerability and capacity have been considered. Similarly, 
in scheming hazard, vulnerability and capacity both ordinal and nominal values were calculated through the model. Fig. 8 is the final yield of flood rink valuation of the study area.

Table 4. Coping capacity, variables and index (Upazila-wise).

\begin{tabular}{|c|c|c|c|c|c|c|}
\hline \multirow{4}{*}{$\begin{array}{l}\text { Sl. } \\
\text { No. }\end{array}$} & \multirow{4}{*}{$\begin{array}{l}\text { Name of the } \\
\text { Upazila }\end{array}$} & \multicolumn{5}{|c|}{ Variables of measuring coping capacity } \\
\hline & & Awareness & $\begin{array}{l}\text { Relief } \\
\text { system }\end{array}$ & $\begin{array}{l}\text { Economic } \\
\text { strength }\end{array}$ & $\begin{array}{l}\text { Use of } \\
\text { indigenous } \\
\text { knowledge }\end{array}$ & $\begin{array}{l}\text { Education } \\
\text { level }\end{array}$ \\
\hline & & Index & Index & Index & Index & Index \\
\hline & & $\begin{array}{l}\text { Very high }=5 \\
\text { High }=4 \\
\text { Medium }=3 \\
\text { Low }=2\end{array}$ & $\begin{array}{l}\text { Very good = } 5 \\
\text { Good }=4 \\
\text { Satisfactory }=3 \\
\text { Not good }=2 \\
\text { Bad = } 1\end{array}$ & $\begin{array}{l}\text { High }=3 \\
\text { Medium = } 2 \\
\text { Low }=1\end{array}$ & $\begin{array}{l}\text { High }=3 \\
\text { Medium }=2 \\
\text { Low }=1\end{array}$ & $\begin{array}{l}\text { Very high }=5 \\
\text { High }=4 \\
\text { Medium }=3 \\
\text { Low }=2 \\
\text { Very low }=1\end{array}$ \\
\hline 1 & Basail & 4 & 4 & 1 & 2 & 2 \\
\hline 2 & Bhaluka & 4 & 5 & 2 & 2 & 2 \\
\hline 3 & Delduar & 4 & 4 & 2 & 2 & 2 \\
\hline 4 & Fulbari & 3 & 3 & 3 & 3 & 3 \\
\hline 5 & Gafargaon & 4 & 2 & 2 & 2 & 2 \\
\hline 6 & Ghatail & 4 & 4 & 2 & 1 & 2 \\
\hline 7 & Gopalpur & 3 & 4 & 1 & 1 & 2 \\
\hline 8 & Jamalpur Sadar & 3 & 3 & 3 & 1 & 3 \\
\hline 9 & Kaliakair & 4 & 5 & 3 & 2 & 4 \\
\hline 10 & Kalihati & 4 & 4 & 1 & 2 & 2 \\
\hline 11 & Madargonj & 4 & 4 & 2 & 1 & 2 \\
\hline 12 & Madhupur & 5 & 4 & 2 & 3 & 2 \\
\hline 13 & Melandaha & 4 & 5 & 1 & 1 & 2 \\
\hline 14 & Mirzapur & 5 & 3 & 2 & 3 & 2 \\
\hline 15 & Muktagacha & 3 & 3 & 2 & 3 & 2 \\
\hline 16 & Sakhipur & 4 & 3 & 2 & 2 & 2 \\
\hline 17 & Sharishabari & 4 & 4 & 2 & 3 & 2 \\
\hline 18 & Tangail Sadar & 4 & 2 & 3 & 1 & 2 \\
\hline 19 & Trisal & 3 & 3 & 2 & 2 & 2 \\
\hline $\begin{array}{l}\text { Inde } \\
\text { Inde }\end{array}$ & $\begin{array}{l}\text { of economic bas } \\
\text { of education (\%) }\end{array}$ & $\begin{array}{l}\mathrm{d} \text { on monthly in } \\
0-20=1,21\end{array}$ & $\begin{array}{l}\text { ome taka } 15000+ \\
0=2,41-60=3,\end{array}$ & $\begin{array}{l}=3,10000- \\
61-80=4,8\end{array}$ & $\begin{array}{l}5000=2,0-1 \\
+=5 .\end{array}$ & $0000=1$ \\
\hline
\end{tabular}




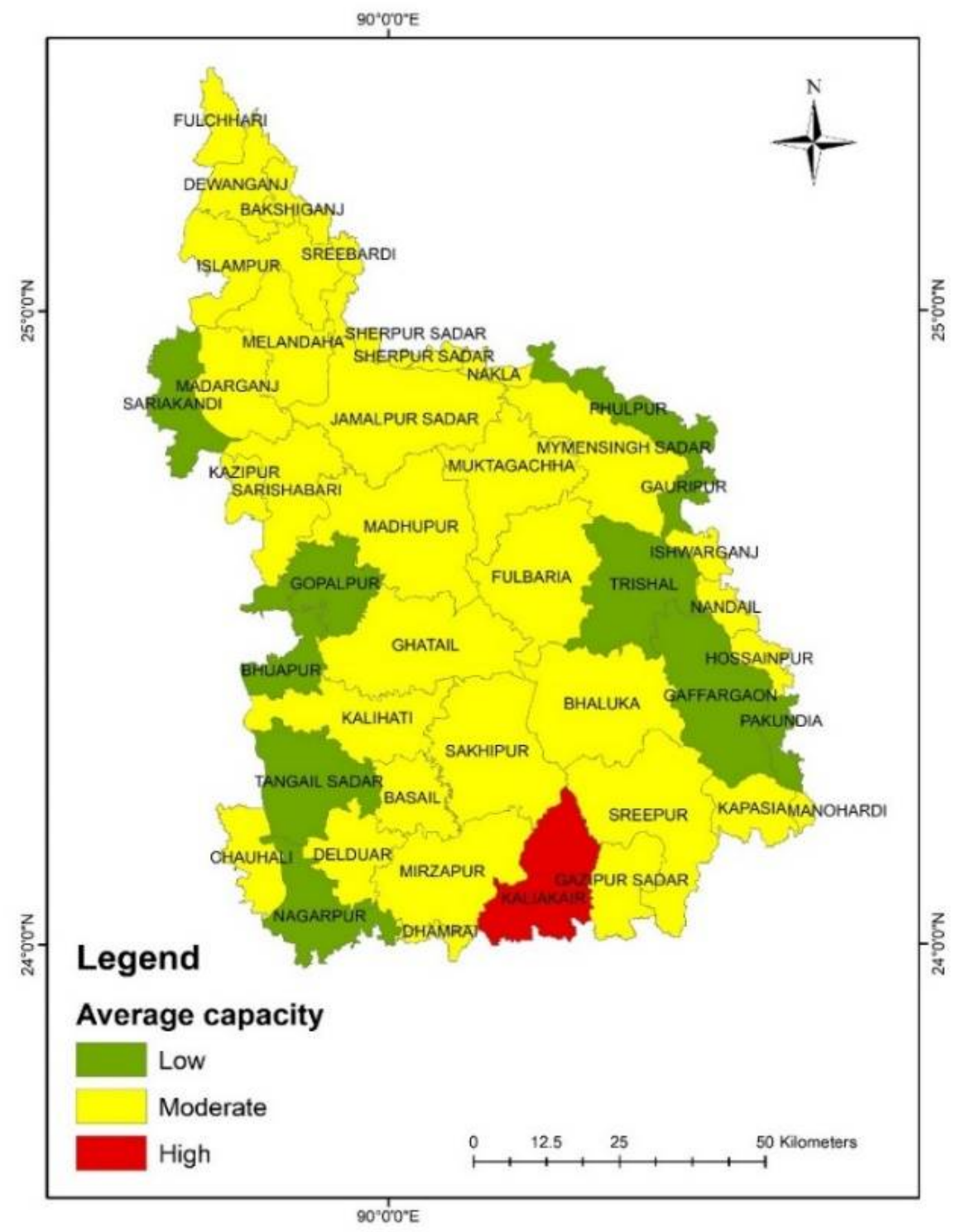

Fig. 7. Average capacity ranking. 


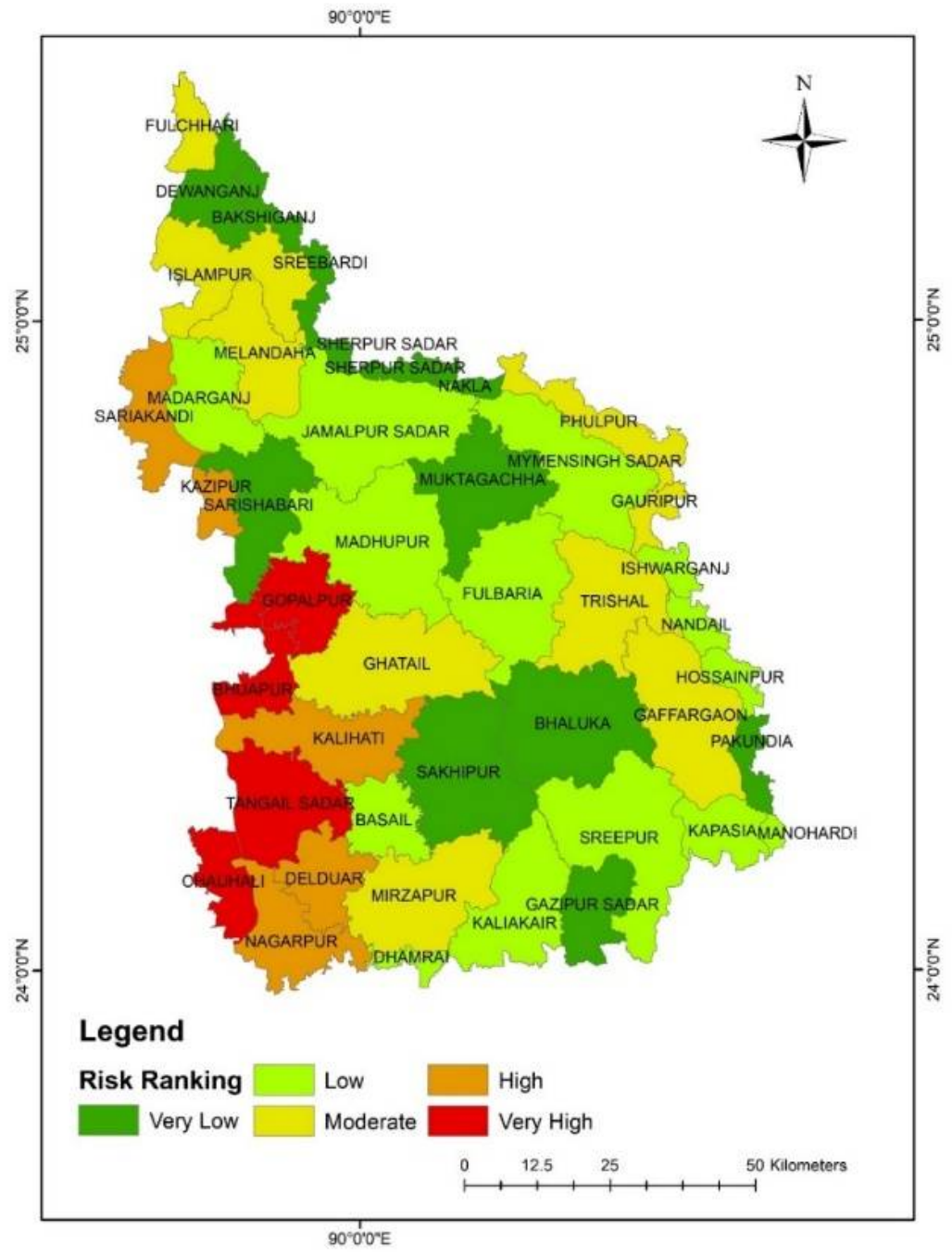

Fig. 8. Flood risk ranking.

\section{Conclusion}

After analyzing all variables stated above, final flood risk has been assessed and is shown in the final map (Fig. 8) which shows the index of flood risk of the Jamuna floodplain. The proposed model could also be applicable for the assessment of flood risk for the whole country as both social and topographical factors have been considered here. This assessment has been conducted to identify the priority areas which should give more 
emphasis for flood mitigation procedures. This type of work is helpful for the planners, disaster management organizations and also for the government to think about the future plan in the considered area.

\section{References}

Bangladesh Bureau of Statistics, 2011. Bangladesh Population and Housing Census 2011.

Cannon, T., 2000. Vulnerability analysis and disasters. Floods 1: 45-55.

Chakraborty, J., G.A Tobin and B.E Montz. 2005. Population evacuation: assessing spatial variability in geophysical risk and social vulnerability to natural hazards. Natural Hazards Review 6(1): 23-33.

Crichton, D. 2002. UK and global insurance responses to flood hazard. Water International 27(1): 119-131.

de Moel, H., B. Jongman, H. Kreibich, B. Merz, E. Penning-Rowsell and P.J. Ward 2015. Flood risk assessments at different spatial scales. Mitigation and Adaptation Strategies for Global Change 20(6): 865-890.

Em-dat, C.R.E.D., 2010. The OFDA/CRED international disaster database. Université catholique.

Meyer, V., D. Haase and S. Scheuer. 2009. Flood risk assessment in European river basins concept, methods, and challenges exemplified at the Mulde river. Integrated Environmental Assessment and Management 5(1): 17-26.

Peduzzi, P., H. Dao, C. Herold. and F. Mouton. 2009. Assessing global exposure and vulnerability towards natural hazards: The disaster risk index. Natural Hazards and Earth System Sciences 9(4): 1149-1159.

Schneiderbauer, S. and D. Ehrlich. 2004. Risk, hazard and people's vulnerability to natural hazards. A review of definitions, concepts and data. European Commission Joint Research Centre. EUR, 21410, 40 p.

Shaluf, Mohamed I. 2007. Disaster types. Disaster Prevention and Management: An International Journal 16(5): 704-717.

Tingsanchali, T. and F. Karim. 2010. Flood-hazard assessment and risk-based zoning of a tropical flood plain: Case study of the Yom River, Thailand. Hydrological Sciences Journal-Journal des Sciences Hydrologiques 55(2): 145-161.

Wisner, B., I. Kelman, T. Monk, J.K. Bothara, D. Alexander, A.M. Dixit, D. Benouar, O.D. Cardona, R. C. Kandel and Petal, M., 2004. School seismic safety: Falling between the cracks? Earthquakes. London, 1-56 pp.

(Revised copy received on 18.11.2018) 